\title{
Millimole per Liter per Milligram per Kilogram per Day
}

National Cancer Institute

\section{Source}

National Cancer Institute. Millimole per Liter per Milligram per Kilogram per Day. NCI

Thesaurus. Code C119415.

A unit of concentration equal to millimoles per liter, divided by milligrams per kilogram per day. 